\title{
Analisa Kebutuhan Pembelajaran Mata Kuliah Bahasa Inggris untuk Mahasiswa Non-Jurusan Bahasa Inggris di Universitas Islam
}

\author{
Alfian \\ Fakultas Adab \& Humaniora UIN Sulthan Thaha Saifuddin Jambi \\ E-mail: alfian@uinjambi.ac.id
}

\begin{abstract}
The purpose of this study is to analyze the needs of students towards English courses for non-English Department students. This research is focused on analyzing the need for teaching materials, desired teaching methods and student language learning strategies. This research is a case study involving 136 Islamic Religious Education (PAI) and Islamic Religion Teacher Education (PGMI) students. The data was collected from respondents by conducting surveys and interviews. Survey data were analyzed using SPSS and Thematic analysis was used to analyze data from interviews. The results of this study indicateed that speaking skill is the skill that is mainly needed by students. Furthermor the development of vocabulary is also the main focus of the students. The results of this study with regard to learning methods show that students like mixed methods. In reference to the learning strategy, the students used variety and wide range of learning strategies. This research is very useful for English language teachers especially for the preparation of the lesson plan for non-English major students.
\end{abstract}

Keywords: Language skills, vocabulary; language learning strategies; teaching methods.

\begin{abstract}
Abstrak: Tujuan penelitian ini adalah untuk menganalisa kebutuhan mahasiswa terhadap Mata kuliah Bahasa Inggris bagi mahasiswa non Jurusan bahasa Inggris. Penelitian ini difokuskan pada kebutuhan materi ajar, metode pengajaran yang diinginkan dan strategi pembelajaran bahasa mahasiwa. Penelitian ini merupakan studi kasus pada mahasiswa Pendidikan Agama Islam (PAI) dan mahasiswa Pendidikan Guru Agama Islam (PGMI) yang melibatkan 136 mahasiwa. Pengumpulan data dari respondents dengan melakukan Survey dan wawancara. Survey data dianalisa dengan menggunakan SPSS dan Tematik analysis digunakan untuk menganalisa data dari wawancara. Hasil penelitian ini menunjukan bahwa keahlian berbicara (speaking) merupakan keahlian yang sangat di perlukan mahasiswa. Selanjutnya pengembangan kosa kata (Vocabulary) juga merupakan focus utama. Hasil penelitian ini berkenaan dengan metode pembelajaran menunjukan bahwa mahasiswa menyenangi metode campuran atau tidak bergantung dengan satu metode saja. Sedangkan strategi belajar yang mereka gunakan dalam belajar bahasa Inggris sangat banyak dan beragam. Penelitian ini sangat bermanfaat bagi pengajar bahasa Inggris terutama untuk penyusunan rencana pembelajaran untuk mahasiswa jurusan non-Bahasa Inggris.
\end{abstract}

Kata-kata kunci: Keahlian berbahasa, kosa kata, strategi belajar bahasa, metode pengajaran 


\section{Pendahuluan}

Bahasa Inggris di tetapkan sebagai mata kuliah wajib di setiap jurusan di perguruan tinggi untuk memenuhi tuntutan kurikulum. Adanya mata kuliah bahasa Inggris tersebut untuk memenuhi tuntutan perkembangan teknologi dan era globalisasi dimana sumber informasi pada umumnya menggunakan bahassa Inggris. Sedangkan, tujuan pembelajaran bahasa Inggris secara umum yaitu agar mahasiswa mampu berkomunikasi dalam bahasa Inggris secara lisan maupun tulisan dengan baik dan mampu memfungsikan bahasa Inggris secara transaksional dan intereaksional yang tercermin dalam 3 kompetensi yaitu sikap spiritual dan sosial), pengetahuan, dan keterampilan 1 .

Fungsi bahasa Inggris di level perguruan tinggi secara transaksional dan intereaksional tercermin dengan adanya beberapa tujuan pembelajaran bahasa Inggris. salah satu tujuan yang mendasar mata kuliah bahasa Inggris sebagai mata kuliah umum adalah bahwa bahasa Inggris merupakan tuntutan kurikulum yang saat ini telah diberlakukan kurikulum Kualifikasi Kerangka Nasional Indonesia (KKNI) yang menempatkan Bahasa Inggris dan salah satu bahasa asing lainnya sebagai mata kuliah wajib di perguruan tinggi. Mata kuliah wajib bahasa Inggris itu sendiri di perlukan dalam rangka membantu mahasiswa untuk mempersiapkan diri dalam mengikuti test TOEFL atau test bahasa Inggris sejenisnya sebagai salah satu syarat untuk mengikuti ujian Munaqosah atau ujian skripsi². Bahasa Inggris juga sangat membantu mahasiswa dalam mengikuti program pertukaran pemuda antar negara karena bahasa Inggris menjadikan salah satu persyaratan pendaftaran program tersebut. Selain itu mata kuliah ini juga diharapkan mampu memberikan gambaran secara umum mengenai keterampilan tertentu yang dibutuhkan mahasiswa dalam menguasai Bahasa Inggris untuk dunia kerja mereka nantinya.

Untuk mencapai tujuan pembelajaran bahasa Inggris bagi jurusan non Bahasa Inggris di perguruan tinggi, pengajaran bahasa Inggris pada umumnya di arahkan kepada pengembangan empat keahlian bahasa (language skills: listening, speaking, reading, writing) dan Komponen bahasa (language compenent : grammar dan vocabulay). Akan tetapi di UIN STS Jambi pembelajaran bahasa Inggris menekankan kepada kemampuan memahami dan mengutip buku - buku ataupun literature - literature berbahasa Inggris yang sesuai dengan jurusan mereka ${ }^{3}$. Sehingga fokus pembelajaran bahasa Inggris hanya pada kemampuan membaca (reading).

Selain terfokus pada kemampuan membaca, dosen pun masih menggunakan bahan ajar berupa handout (reading text) yang di foto copy

1 Permendikbud. (2013). Permendikbud nomor 64 tahun 2013 tentang Standar isi. Jakarta: Badan Standar Nasional Pendidikan.

${ }^{2}$ Buku Pedoman UIN STS Jambi Tahun Akademik 2017/2018

${ }^{3}$ Workshop Dosen Bahasa Inggris. (2106). Orientasi Pembelajaran Bahasa Inggris di UIN. Gedung MUI Provinsi Jambi. 
dimana konten dari teks bacaan tersebut masih bersifat bacaan bahasa Inggris umum. Sementara kebutuhan Bahasa Inggris di perguruan tinggi sebenarnya lebih kepada sebagai alat bantu bagi mahasiswa dalam memahami teks yang berkaitan dengan bidang mereka (Bidang agama Islam) dan pengembangan keahlian bahasa serta pengembangan komponen bahasa. Oleh karena itu mengajarkan mahasiswa Bahasa Inggris dengan fokus pada keterampilan dasar pada kemampuan membaca saja (reading) bacaan yang bersifat umum menjadi tidak begitu efisien dan efektif karena mereka dituntut juga untuk menguasai istilah - istilah berbahasa Inggris dalam bidang mereka.

Sejalan dengan dengan tuntutan penguasaan istilah - istilah dalam bahasa Inggris untuk bidang studi tertentu, Kurikulum KKNI juga menuntut adanya rumusan luaran belajar yang menuntut kompetensi untuk bekerja, ilmu yang harus dikuasai, serta kemampuan manajerial dan pengembangan diri $^{4} 5$, maka sudah seharusnya pembelajaran bahasa Inggris diarahkan kepada pembelajaran bahasa Inggris untuk tujuan khusus (English for specific purposes/ESP). English for specific Purposes (ESP) berbeda dengan bahasa Inggris untuk tujuan umum (General Generla English). Menurut Robinson ESP "is generally used to refer to the teaching and learning of a foreign language for a clearly itilitarian purpose of which there is no doubt.6" Dengan kata lain tujuan ESP adalah agar mahasiswa mampu menguasai Bahasa Inggris pada bidang yang mereka pelajari. Artinya materi yang diberikan haruslah disesuaikan dengan kebutuhan peserta didik. Hal ini berkaitan dengan istilah yang digunakan ataupun kosa kata dan jenis wacana yang ataupun jenis percakapan yang biasanya terjadi dalam disiplin ilmu yang berbeda7. Misalnya mahasiswa Matematika, maka mereka seharusnya harus mendapatkan materi dan memahami Bahasa Inggris untuk matematika, atau jika mereka mahasiswa Pendidikan Agama Islam, mereka seharusnya mengetahui istilah - istilah Bahasa Inggris yang berhubungan dengan Pendidikan Agama Islam, jika mereka mahasiwa ekonomi, mereka seharusnya menguasai istilah-istilah ekonomi dalam bahasa Inggris, dan sebagainya.

Berkaitan dengan adanya tujuan tertentu dalam pembekajaran bahasa Inggris, Donough (1984) menyarankan bahwa materi dan silabus serta tujuan ESP harus dirancang dan dikembangkan berdasarkan kebutuhan mahasiswa dan pengguna lulusan. Jadi pendekatan ESP adalah pendekatan dari bawah ke atas (button up approach) ${ }^{8}$. ESP merupakan pendekatan

4 Solikhah, Imrotus. (2016). Pengembangan model kurikulum pendidikan bahasa Inggris berbasis KKNI. konstruktivisme, Vol. 8, No. 1.

5 Peraturan Presiden Nomor 8 Tahun 2012. Kerangka Kualifikasi Nasional Indonesia. Jakarta: Sekretariat Negara

${ }^{6}$ Robinson, Paulina (1990). English For Specific Purposes. Oxford: Pergamon Press, Ltd.

${ }^{7}$ Hutchinson, T \& Waters, A. (1987). English for specific purposes: A learning-centered approach. Cambridge: Cambridge University Press.

${ }^{8}$ Donough, Jo.Mc. (1984). ESP in Perspective A Practical Guide. London: Collin ELT 
khusus dalam pembelajaran Bahasa Inggris yang berbeda dengan Bahasa Inggris umum. ESP merujuk pada pembelajaran Bahasa Inggris yang berorientasi kebutuhan khusus pembelajar sesuai dengan bidang ilmu dan pekerjaan mereka. Untuk mengimplementasikan bahasa Inggris sebagai tujuan khusus dibutuhkan materi ajar yang tepat sasaran karena materi ajar memainkan peranan penting dalam menentukan kesuksesan pembelajaran?. Sehingga bahasa Inggris untuk tujuan khusus atau ESP mestilah ditempatkan sebagai alat bagi mahasiswa di perguruan tinggi sebagai penunjang studi mereka. Untuk itu fokus pembelajaran Bahasa Inggri seharusnya adalah pada isi dari materi ajar dan pengembangan terhadap keempat keterampilan dasar serta komponen bahasa.

Sehubungan dengan pemilihan dan penyusunan materi ajar serta kegiatan mahasiswa dalam pembelajaran, seharusnya tidak hanya di fokuskan kepada satu keahlian bahasa saja atau keahlian bahasa dan komponen bahasa (language skills dan language components), namun juga di arahkan kepada pengembangan kepribadian atau sikap, pengetahuan tentang bidang studinya. Menurut Mulyasa, pemilihan bahan ajar handout dengan foukus reading yang umum atau ketrampilan lainnya telah mengabaikan pengetahuan tentang jurusan, keterampilan, dan sikap yang harus dipelajari siswa dalam rangka mencapai capaian pembelajaranya ${ }^{10}$.

Telah banyak penelitian tentang pengembangan materi perkuliahan/ materi ajar dan strategi pembelajaran serta metode pengajaran. Dalam hal pengembangan materi ajar Rizal dalam penelitiannya menyimpulkan bahwa materi /bahan ajar bahasa Inggris yang termuat dalam buku bahan ajar bahasa Inggris MKDU IAIN Bengkulu belum sesuai dengan apa yang sesungguhnya dibutuhkan para mahasiswa Jurusan PGMI dan PAI Fakultas Tarbiyah UIN Bengkulu11. Hasil penelitan ini sama dengan hasil penelitian Yaumi yang meneliti tentang pengembangan bahan ajar ESP berbasis TIK yang dilakukan di Makasar. Dengan menggunakan teori pengembangan bahan ajar dari Borg (1983), Yaumi juga menyimpulkan bahwa materi atau bahan ajar ESP untuk mahasiswa belum sesuai dengan kebutuhan mahasiswa dan materinya pada umumnya belum sesuai dengan bidang ilmu tertentu 12 .

Sehubungan dengan penelitan dalam hal materi keahlian berbahasa yang dibutuhkan mahasiswa, hasil penelitian menunjukan bahwa keahlian

9 Karamouzian, F.M. (2010). A Post-Use Evaluation of Current Reading ComprehensionTextbooks Used in TEFL Programs. The Iranian EFL Journal. Volume 6 Issue 4. pp 24-62

10 Mulyasa E. 2006. Kurikulum Yang Disempurnakan. Bandung: PT Remaja Rosdakarya

${ }^{11}$ Rizal, S. (2013). Analisis kebutuhan bahan ajar bahasa Inggris UIN bengkulu melalui students' need analysis. At-ta'lim, vol. 12, no. 2.

12 Yaumi, M. (2012). Pengembangan bahan ajar Englis for specific Purpose berbasis TIK.. Lentera Pendidikan, (15) No.2. 144-160 
berbicara merupakan keahlian yang paling tinggi diminati mahasiswa 13 . Hasil penelitian ini sama dengan penelitian yang dilakukan oleh Boroujeni and Fard (2013) bahwa kemampuan berbicara merupakan keahlian yang sangat diutamakan mahasiwa. Dua penelitian ini menyatakan bahwa kemampuan speaking sangat dibutuhkan oleh mahasiswa karena terlah melakukan analisa kebutuhan sebagaimana yang dikemukakan oleh Agusliana, Rachmawati, Hardjono ( 2014) dan Hakim (2016) yang menyatakan bahwa pengembangan bahan ajar speaking harus melalui analisa kebutuhan awal sehingga menghasil materi ketrampilan berbicara yang efektif ${ }^{14}$.

Berdasarkan hasil penelitian diatas dan pengalaman dan pengamatan peneliti, selama ini bahan/materi ajar yang digunakan dosen di UIN STS Jambi masih berupa handout dan lembaran -lembaran kertas yang di foto copy yang diperoleh dari internet dan berbagai sumber serta di rancang ke dalam power point. Hasil pengamatan ini sejalan dengan yang dikemukakan oleh Yaumi (2012) yang mengemukakan bahwa bahan ajar yang dipakai dosen masih berupa bahan cetak berupa hand out, ringkasan materi, dan materi penyajian dalam bentuk Powerpoint ${ }^{15}$. Hal ini menunjukan bahwa belum adanya buku ajar yang sesuai untuk di gunakan dalam proses belajar dan mengajar khususkan di UIN/UIN. Sedangkan untuk lebih terarahnya perkuliahan dan tertatanya materi perkuliahan yang sesuai dengan kebutuhan mahasiswa di jurusan tertentu, bahan ajar berupa buku ajar/teks yang baku hendak nya di rancang secara khusus.

Selain bahan ajar yang tepat yang meliputi empat skills berbahasa dan dua komponen bahasa yaitu Grammar dan Vocabulary, strategy belajar mahasiswapun dan metode pengajaran sangat perlu dikembangkan. Menurut Oxford, istilah strategy belajar bahasa mengacu pada "the learner's goaldirected actions for improving language proficiency or achievement, completing a task, or making learning more efficient, more effective, and easier" atau "learning skills, learning to learn skills, thinking skills, and problem solving skills"16 yang dalam Bahasa Indonesianya keahlian belajar, belajar mempelajari skill, keahlian berpikir, dan keahlian memecahkan masalah bagi pembelajar supaya lebih efisien effecktif dan mudah. Strategy belajar ini secara garis besar di bagi kedalam enam strategy yaitu memory,

13 Wikrama, I. A. (2017). Developing English Materials for Students of Management Department: Business Law \& Islamic Economic at Sekolah Tinggi Ilmu Ekonomi Yayasan Pendidikan Ujung Pandang (STIE YPUP) (Doctoral dissertation, Universitas Islam Negeri Makassar).

14 Agusliana, A., Rachmawati, R., \& Hardjono, H. S. (2014). Pengembangan materi pembelajaran keterampilan berbicara bahasa Inggris di smp. Jurnal Tekno-pedagogi, 4(1).

15 Yaumi, M. (2012). Pengembangan bahan ajar Englis for specific Purpose berbasis TIK.. Lentera Pendidikan, (15) No.2. 144-160

16 Oxford, R. L. (2011). Strategies for learning a second or foreign language. Language Teaching, 44(02), 167-180. 
cognitive, compensation, metacognitive, affektif dan social strategi ${ }^{17}$. Strategi-strategi belajar bahasa yang di paparkan ini menjadi landasan teori pembelajaran bahasa sebagai acuan awal tentang cara belajar mahasiswa. Sehubungan dengan penelitian strategi belajar bahasa, hasil penelitian menunjukan bahwa strategi metcognitive banyak digunakan mahasiswa. Misalnya penelitian Song (2004) menyatakan bahwa strategi metacognitive paling sering digunakan ${ }^{18}$. Hal ini sama dengan penelitian Gerami and Baighlou (2011) yang menemukan bahwa mahasiswa yang berhasil mengunakan strategi metacognitive. ${ }^{19}$ Hasil penelitian yang dilakukan oleh Annurahman, Kurniawati, \& Ramadhiyanti (2013) dan Alfian (2016) juga menyatakan bahwa strategi metacognitive sangat banyak digunakan mahasiswa 20 21. Dengan adanya cara/ strategy belajar mahasiswa dan hasil penelitiannya, maka kegiatan - kegiatan pembelajaran mahasiswa dapat dirancang dengan baik.

Berdasarkan paparan yang dikemukan di atas dapat disimpulkan bahwa ada beberapa hal penting yang perlu di perhatikan untuk tercapainya tujuan perkuliahan bahasa Inggris di perguruan tinggi. Pertama, bahan ajar/atau materi perkuliahan Bahasa Inggris hendaknya sesuai dengan kebutuhan mahasiswa untuk tujuan khusus jurusan (ESP) sehingga mereka dapat meningkatkan pemahaman terhadap literature di bidang mereka dan meningkatkanan keahlian berbahasa lainnya serta menambah kosa kata di bidang keahlian mereka. Selanjutnya didalam kurikulum berbasis KKNI dinyatakan bahwa penyusunan bahan ajar harus di sesuaikan dengan profil lulusan dan capaian pembelajaran pada setiap jurusan ${ }^{22}$. Kedua, pengimplementasian metode pembelajaran harus sesuai dengan tuntutan kurikulum. Ketiga, perlu adanya strategi dan cara dalam belajar bahasa Inggris dan metode pengajaran oleh pengajar bahasa Inggris. Untuk memberikan solusi terhadap permaslahan- permasalahan ini, maka perlu adanya analisa kebutuhan ke dalam ketiga hal yang tersebut sebelumnya. Hal ini sesuai dengan apa yang dikemukan oleh Mc Donough (1984) yang menyatakan bahwa "ESP courses are those where the syllabus and materials are determined in all essentials by prior analysis of the communication needs of

17 Oxford, R. L. (1990). Language learning strategies : what every teacher should know. New York: Newbury House Publisher.

18 Song, X . (2004). Language learning strategy use and language performance for Chinese learners of English.Dissertation. Canada: Queen's University. Retrieved on March, 2006 from http://micro189.lib3.hawaii.edu:2132/dissertations/dlnow/MQ99642.

${ }^{19}$ Gerami, Mohammad Hossein, \& Baighlou, Shiva Madani Ghareh. (2011). Language Learning Strategies Used by Successful and Less successful Iranian EFL Students. Procedia Social and Behavioral Sciences, 29(0), 1567-1576. doi: 10.1016/j.sbspro.2011.11.399

20 Alfian, A. (2016). The Application of Language Learning Strategies of High School Students in Indonesia. IJEE (Indonesian Journal of English Education), 3(2), 140-157.

21 Annurahman, kurniawati, T., \&Ramadhiyanti, Y. (2013). Exploring Indonesian college students strategies in Learning English Language.AWEJ, 4(3), 317 -330

22 Ibid 
the learners." Oleh karena itu, paper ini bertujuan untuk mengemukakan hasil penelitian yang berhubungan dengan materi pembelajaran yang di perlukan oleh mahasiswa non jurusan bahasa Inggris, strategi pembelajaran Bahasa Inggris, dan metode pengajaran yang di kehendaki oleh mahasiswa.

Penelitian ini dilakukan untuk menginvestigasi mater/bahan ajar Mata kuliah bahasa Inggris untuk jurusan non bahasa Inggris dan untuk melihat strategy serta metode pembelajaran bahasa Inggris di salah satu perguruan tingggi keagamaan Islam (PTKI) di Indonesia, sehingga penelitian ini lebih tepatnya merupakan studi kasus (case study). Pengumpulan data penelitian ini dilakukan dengan cara survey kepada mahasiswa di PTKI pada jurusan Non Bahaha Inggris dan melakukan wawancara (interview). Sebanyak 136 mahasiswa PAI dan PGMI ikut ambil bagian dalam mengisi survey tentang materi pembelajaran bahasa Inggris dan strategi belajar bahasa Inggris serta metode pembelajaran. Selanjutnya FGD dilakukan dengan 2 kelompok masing-masing 5 orang.

Proses analisa data terdapat dua tahap. Tahap pertama, peneliti menggunakan SPPS (statistical product for Social science) sebuah software yang dikembangkan oleh IBM untuk menganalisa hasil angket strategi belajar. Dalam SPSS data descriptive seperti mean, frequency dan percentage digunakan untuk mengidentifikasi strategi dan tingkat pemakaian strategi yang digunakan oleh mahasiswa. Selanjutnya angket kebutuhan mahasiswa akan di tabulasi.

Tahap kedua, peneliti menganalisa data dari hasil wawancara dengan menggunakan metode deskriptif kualitatif yaitu data digambarkan dengan kata-kata atau kalimat yang dipisah-pisahkan menurut kategori untuk memperoleh kesimpulan ${ }^{23}$ (Arikunto, 1998). Dengan kata lain metode analisa data ini menggunakan metode tematik analisis termasuk memberikan kode, pengelompokan dan memunculkan tema (coding, categorizing and emerging theme $)^{24}$.

\section{Materi pembelajaran Bahasa Inggris}

Hasil analisa data dari hasil survey mahasiswa berhubungan dengan keahlian dan komponen bahasa serta materi ajar yang dibutuhkan oleh mahasiswa dapat dilihat pada tabel 1 berikut: Jakarta.

23 Arikunto, S. (1998). Prosedur Penelitian Suatu Pendekatan Praktek. Rineka Cipta,

${ }^{24}$ Fielding, J. (2008). Coding and managing data. In G. N (Ed.), Researching social life (3 ed.). London: Sage Publication Ltd. 


\begin{tabular}{llc}
\hline No & $\begin{array}{l}\text { Keahlian dan komponen } \\
\text { bahasa }\end{array}$ & Persentase (\%) \\
\hline 1 & Mendengar & 9 \\
\hline 2 & Berbicara & 43 \\
\hline 3 & Membaca & 3 \\
\hline 4 & Menulis & 11 \\
\hline 5 & Kosa kata & 29 \\
\hline 6 & Tata bahasa & 6 \\
\hline
\end{tabular}

Ditinjau dari keahlian berbahasa (4 language skills) dan komponent bahasa (language component), maka yang paling utama yang dibutuhkan mahasiswa adalah pengajaran berbicara ( speaking) dan pengembangan kosa kata (Vocabulary). Hal ini dapat dilihat dari besarnya jumlah presentase yang dilaporkan oleh mahasiswa. $43 \%$ dari mahasiswa menyatakan bahwa skills yang paling utama diajarkan adalah keahlian berbicara (speaking). Sedangkan komponen bahasa yang perlu diajarkan adalah kosa kata. Namun beberapa mahasiswa memilih keahlian dan komponen bahasa lain sebagai materi utama dalam pembelajaran bahasa Inggris. Hal ini dapat disimpulkan bahwa mahasiswa yakin bahwa semua keahlian dan komponen bahasa sangat perlu di masukan kedalam materi pembelajaran bahasa Inggris.

Dari table diatas dapat disimpulkan bahwa materi tentang ketrampilan berbicara (speaking) dan pengembangan kosa kata (vocabulary) dianggap hal yang terpenting dalam pembelajaran bahasa Inggris. Hal ini karena mereka menganggap tujuan belajar bahasa adalah untuk berkomunikasi dalam bahasa tersebut. Sehingga mereka juga harus mengembangkan kosa kata mereka untuk mencapai tujuan tersebut. Namun seperti yang disampaikan di atas bahwa semua ketrampilan dan komponen bahasa harus di masukan kedalam materi ajar. Ini artinya seorang dosen harus mampu mengintegrasikan beberapa keahlian (Language skills) dalam satu kali pertemuan.

Temuan yang signifikan tentang materi pembelajaran yang mencakup keempat skills berbahasa dan peningkatan kosa kata (vocabulary) dan tata bahasa (grammar) menunjukan bahwa materi pembelajaran haruslah mencakup untuk peningkatan keahlian berbahasa dan peningkatakan kosa kata serta tata bahasa. Dari keempat keahlian berbahasa tentu sesuai dengan hasil temuan bahwa peningkatan kemampuan berbicara dan pengembangan kosa kata merupakan tujuan utama dari pembelajaran bahasa Inggris di jurusan keagamaan di PTKIN. Hal ini disebakan bahwa mereka yakin dengan peningkatan kemampuan berbicara dan peningkatan kosa kata mereka akan dapat berkomunikas dalam bahasa Inggris sesuai dengan tujuan pembelajaran bahasa Inggris itu sendiri yaitu untuk mampu berkomunikasi dengan baik dalam bahasa Inggris baik lisan maupun tulisan 25 
Alfian

\section{Metode Pengajaran dan Strategi Belajar}

Temuan dari hasil analisa data yang berhubungan dengan metode pengajaran dosen dan strategi belajar bahasa mahasiswa dapat dilihat pada tabel 2 berikut ini.

\begin{tabular}{|c|c|}
\hline \multirow{16}{*}{$\begin{array}{l}\text { Strategi belajar } \\
\text { bahasa mahassiwa }\end{array}$} & Menonton film \\
\hline & Menghapal kosa kata \\
\hline & Mempraktekan \\
\hline & Menulis \\
\hline & Berbicara \\
\hline & Membaca, article, novel, cerita \\
\hline & Mengulangi /repetition \\
\hline & belajar melalui you tube \\
\hline & Mendengar musik \\
\hline & Tanya jawab \\
\hline & Bercanda dalam bhs Inggris \\
\hline & Ikut kursus bahasa Inggris \\
\hline & Menirukan \\
\hline & Permainan \\
\hline & $\begin{array}{l}\text { Menghapal menggunakan social } \\
\text { media }\end{array}$ \\
\hline & Mengucapkan kata-kata \\
\hline \multirow[t]{8}{*}{$\begin{array}{l}\text { Metode/teknik } \\
\text { pengajaran dosen }\end{array}$} & $\begin{array}{l}\text { Memperbanyak game } \\
\text { Menyenangkan dan tidak tegang. } \\
\text { Mendengar lagu }\end{array}$ \\
\hline & Tanya jawab \\
\hline & Penjelasan \\
\hline & Menggunakan bahasa Inggris \\
\hline & Pengajaran kosa kata \\
\hline & $\begin{array}{l}\text { Meminta mahasiswa banyak } \\
\text { praktek }\end{array}$ \\
\hline & Ceramah \\
\hline & presentasi \\
\hline
\end{tabular}


Tabel diatas menunjukan asil wawancara sehubungan dengan strategi belajar bahasa dan metode pengajaran. Lebih dari sepuluh strategi atau cara yang mereka lakukan dalam meningkatkan bahasa Inggris mereka diantaranya yang paling utama dan sesuai dengan metode pengajaran yang mereka harapkan adalah mempraktek bahasa Inggris, mempraktekan empat keahlian berbahasa serta menghapal atau menambah kosa kata mereka. Selain hal tersebut cara lain utnuk meningkatkan bahasa Inggris mereka, mereka memanfaatkan media dan tecknologi seperti TV, tape recorder, media sosial seperti You tube, Facebook, dan lain sebagainya. Sebagian besar strategi-strategi ini dikategorikan kedalam strategi metocognitif.

Hasil ini menunjukan bahwa para mahasiswa menggunakan berbagi macam strategi untuk meningkatkan bahasa Inggris mereka. Diantara strategi yang paling sering dikemukan mahasiswa adalah menghapal kosa kata kemudian memakai kosa kata tersebut sehari-hari. Selain strategi ini, mempraktekan empat keahlian berbahasa juga sangat banyak digunakan oleh mahasiswa. Akan tetapi strategi yang paling baik menurut mereka adalah mereka mengikuti kursus bahasa Inggris. Kursus untuk meningkatkan kemampuan berbahasa, diantaranya dengan mahasiswa belajar langsung mereka akan bisa langsung berintereaksi dengan mahasiswa. Selain hal itu pembelajaran di kursus juga sudah terarah karena memiliki kurikulum yang tersusun sesuai dengan tingkat kemahiran mereka dalam bahasa Inggris. Selain mengikuti kursus bahasa Inggris para mahasiswapun menggunakan strategi menparaktekan keempat keahlian berbahasa. Namun yang lebih utama yang mereka lakukan adalah praktek berbicara. Hal ini sesuai dengan hasil penelitian pada bagian keempat keahlian yang mereka utamakan seperti di atas.

Dari segi metode pengajaran diinginkan mahasiswa, secara garis besar mahasiswa menyatakan bahwa dosen dalam mengampu mata kuliah bahasa Inggris hendaknya mampu membuat suasana kegiatan perkuliahan yang bervariasi dan menyenangkan. Hal ini dapat dilakukan dengan tanya jawab, meminta/ memperbanyak mahasiswa mempraktekan, penjelasan / presentasi yang cukup dari dosen kelas, membuat game serta kegiatan lainnya yang dapat meningkatkan keahlian berbahasa dana menambah kosa kata mereka.Metode pengajaran yang diiginkan mahasiswa ini juga sejalan dengan hasil survey tentang strategi belajar bahasa yang dikemukan oleh mahasiswa. Survey ini menunjukan bahwa berbagai macam cara atau strategi yang dilakukan oleh mahasiswa dalam meningkatkan kemampuan bahasa Inggris mereka. Maka mereka berharap agar metode pengajaran juga bervariasi.

Dari uraian diatas didapat bahwa para mahasiswa menggunakan berbagai macam cara dalam meningkatkan kemampuan bahasa Inggris mereka dan mereka menginginkan berbagai metode pengajaran. Hal ini menunjukan bahwa para mahasiswa dalam penelitian ini mencari berbagai 
cara/ strategi dalam meningkatkan kemampuan bahasa Inggris. Hal ini sangat erat hubungannnya dengan "strategy awareness" atau kesadaran dalam mencari strategi - strategi untuk meningkatkan kemampuan Inggris secara umum. Lee and Oxford (2008) menegaskan bahwa strategy awareness atau kesadaran tentang pentingnya strategi sangat membantu pembelajar bahasa menggunakan strategi - strategi. Hal ini akan membawa mahasiswa menjadi pembelajar bahasa yang baik.

Refleksi dari hasil yang didapatkan bahwa para mahasiswa telah menyadari pentingnya strategi -strategi yang dapat digunakan dalam peningkatan kemampuan bahasa Inggris mereka. Beberapa strategi yang mereka anggap sangat penting seperti yang terdapat dalam hasil penelitian ini dan juga termasuk membaca buku bahasa Inggris,novel, majalah, berbicara, mendengarkan dan menulis, melakukan diskusi dengan pembelajar bahasa Inggris lainnya (Oxford, 1990).

\section{Penutup}

Materi pembelajaran berdasarkan tujauan dan output ataupun luaran yang mereka harapkan maka materi yang diharapkan oleh mahasiswa adalah materi pembelajaran keahlian berbahasa yang meliputi 4 keahlian berbahasa (language Skills) dan 2 komponen bahasa (language component). Namun materi bahasa Inggris untuk Non jurusan bahasa Inggris lebih menekankan pada peningkatan kosa kata (vocabulary) dan keahlian berbicara (speaking). Dengan adanya temuan ini sudah barang tentu para dosen harus merumuskan silabus pembelajaran dengan baik yang mencakup semua hal tentang pembelajaran bahasa. Dengan katan lain capaian pembelajaran harus di susun dengan baik dalam pembuatan Rencana pembelajaran Semester (RPS). Dan kalupun bahan ajar ataupun buku ajar belum terdapat maka seorang dosen hendaknya mencari referensi tentang bahan ajar yang baik.

Ditinjau dari segi Metode/teknik pengajaran dosen dan strategi belajar bahasa mahasiswa. Hasil penelitian ini menunjukan bahwa dosen masih menggunakan teacher centered atau yang lebih dikenal dengan pembelajaran tradisional. Banyak harapan dari mahasiswa bahwa metode yang digunakan hendaknya metode integratif atau di fokuskan ke metode student centred. Dimana pembelajaran berpusat kepada mahasiswa. Sehubungan dengan cara belajar mahasiswa, mahasiswa menggunakan berbagai macam cara dalam pembelajaran. Namun dapat dilihat bahwa mereka belum mengenal srtategistrategi pembelajaran bahasa yang banyak. sehingga mereka masih belum begitu bisa mengemukakan strategi-strategi pembelajaran bahasa sebagimana yang dikemukan oleh ahli pembelajaran bahasa.

Penelitian ini diharapkan dapat memberikan acuan bagi dosen untuk mengembangkan bahasa ajar bahasa Inggris. Seorang tenaga pengajar diharapkan juga dapat merancang materi ajar yang sesuai dengan kebutuhan 
mahasiswa. Secara metodologi penelitian ini memiliki keterbatasan dalam hal populasi dan sampel dimana hanya dua program studi yang di teliti. Penelitian selanjutnya diharapkan melibatkan paling tidak tiga program studi sehingga datanya lebih bisa di silangkan.

\section{Bibliografi}

Alfian, A. (2016). The Application of Language Learning Strategies of High School Students in Indonesia. IJEE (Indonesian Journal of English Education), 3(2), 140-157.

Annurahman, kurniawati, T., \&Ramadhiyanti, Y. (2013). Exploring Indonesian college student strategies in Learning English Language.AWEJ, 4(3), $317-330$.

Agusliana, A., Rachmawati, R., \& Hardjono, H. S. (2014). Pengembangan materi pembelajaran keterampilan berbicara bahasa Inggris di smp. Jurnal Tekno-pedagogi, 4(1).

Arikunto, S. (1998). Prosedur Penelitian Suatu Pendekatan Praktek. Rineka Cipta, Jakarta.

Boroujeni, S.A. \& Fard, F.M. (2013). A need analysis of English for specific purposes (ESP) course for adoption of communicative language teaching: (A case of Iranian first-year of educational administration. International Journal of Humanities and Social Science Invention. Vol. 2. 6. 35-44.

Fielding, J. (2008). Coding and managing data. In G. N (Ed.), Researching social life ( 3 ed.). London: Sage Publication Ltd.

Borg, W.R. (1981). Applying Educational Research. New York: Longman.

Donough, Jo.Mc. (1984). ESP in Perspective A Practical Guide. London: Collin ELT

Hakim (2016). Pengembangan materi bahan ajar public speaking berbasis communicative language teaching bagi mahasiswa di Indonesia. Manhaj: Jurnal penelitian dan pengabdian masyarakat, 4(3), 229-238.

Karamouzian, F.M. (2010). A Post-Use Evaluation of Current Reading Comprehension Textbooks Used in TEFL Programs. The Iranian EFL Journal. Volume 6 Issue 4. pp 24-62

Hutchinson, T \& Waters, A. (1987). English for specific purposes: A learningcentered approach. Cambridge: Cambridge University Press.

UIN STS Jambi. (2106). Buku Pedoman UIN STS Jambi 2016/2017. UIN STS Jambi

Mulyasa E. 2006. Kurikulum Yang Disempurnakan. Bandung: PT Remaja Rosdakarya

Oxford, R. L. (2011). Strategies for learning a second or foreign language. Language Teaching, 44(02), 167-180. 
Alfian

Oxford, R. L. (1990). Language learning strategies: what every teacher should know. New York: Newbury House Publisher.

Peraturan Presiden Nomor 8 Tahun 2012. Kerangka Kualifikasi Nasional Indonesia. Jakarta: Sekretariat Negara.

Robinson, Paulina (1990). English For Specific Purposes. Oxford: Pergamon Press, Ltd.

Rizal, S. (2013). Analisis kebutuhan bahan ajar bahasa Inggris UIN bengkulu melalui students' need analysis. At-ta'lim, vol. 12, no. 2.

Solikhah, Imrotus. (2016). Pengembangan model kurikulum pendidikan bahasa Inggris berbasis KKNI. konstruktivisme, Vol. 8, No. 1.

Song, X . (2004). Language learning strategy use and language performance for Chinese learners of English.Dissertation. Canada: Queen's University. Retrieved on March, 2006 from http://micro189.lib3.hawaii.edu:2132/dissertations/dlnow/MQ9964 2.

Tomlinson, B. (Ed.). 1998. Materials Development in Language Teaching. Cambridge: Cambridge University Press.

Wikrama, I. A. (2017). Developing English Materials for Students of Management Department: Business Law \& Islamic Economic at Sekolah Tinggi Ilmu Ekonomi Yayasan Pendidikan Ujung Pandang (STIE YPUP) (Doctoral dissertation, Universitas Islam Negeri Makassar).

Workshop Dosen Bahasa Inggris. (2106). Orientasi Pembelajaran Bahasa Inggris di UIN. Gedung MUI Provinsi Jambi.

Yaumi, M. (2012). Pengembangan bahan ajar Englis for specific Purpose berbasis TIK. Lentera Pendidikan, (15) No.2. 144-160. 
Analisa Kebutuhan Pembelajaran Mata Kuliah Bahasa Inggris 